\title{
The Effect of Fiber -Protein Levels on Milk Parameters, Linear Body Measurements and Udder Dimensions of West African Dwarf Sheep at First Lambing
}

\section{Adewumi OO* and Ahmed AA}

Department of Animal Production and Health, Federal University of Agriculture, Abeokuta, Ogun State, Nigeria

\begin{abstract}
A study on the effect of dietary fiber -protein levels on milk parameters and performance of West African Dwarf ewes and their lambs at first lambing was investigated for twelve weeks. The experimental diet includes control (CTRL), low fiber high protein (LFHP), and high fiber low protein (HFLP). Diet significantly $(p<0.05)$ influenced milk fat and fat-protein ratio of the milk, feed intake and milk off take but did not significantly $(p>0.05)$ influenced total solids and protein content. The LFHP diet was the most consumed $(P<0.05)$ compared to other diets and it induced higher percentage of milk offtake, fat and protein content. Lactating ewes on LFHP were significantly superior in weight, body parameters and udder dimensions except wither height and teat length that had significantly higher values in HFLP and CTRL diet respectively. Lambs on LFHP diet were significantly superior in weight and body parameters. No significant difference was detected among diets for heart girth and udder width in lactating ewes and for body length and neck circumference in their lambs. The fat/protein ratio of LFHP and CRTL diets indicated sufficient supply of energy and fiber as compared to diet on HFLP. Feed cost was highest in control diet but lowest for high fiber -low protein diet. Since dietary low fiber high protein improved the milk and body parameters, low fiber high protein (LFHP) diet should be formulated for lactating ewes to enhance the performance of WAD and their lambs at first lambing.
\end{abstract}

Keywords: Fiber -protein levels; Milk parameters; West African dwarf sheep; Dairy ruminants

\section{Introduction}

Level of nutrition, mainly referred to energy level or level of feed intake, is a main factor affecting milk yield and milk composition in dairy ruminants. While there have been some reports on the effect of nutrition on milk, body and udder parameters in temperate breeds of sheep $[1,2]$, not much has been done to estimate the effect of nutrition on milk, body and udder parameter of Nigerian sheep and the performance of their lambs. There is a growing awareness of the need to provide more information on the Nigerian sheep in general and the West African Dwarf sheep in particular as sources of meat and milk. The West African Dwarf sheep is the predominant breed of the humid tropics from South West Africa through Central Africa. This breed is trypanotolerant, hardy and has high quality milk [3]. Therefore, this study was conducted to determine the effect of dietary fiber -protein level on milk parameters and performance of West African Dwarf sheep at first lambing.

\section{Materials and Methods}

\section{Experimental animals and their management}

Nine lactating (West African Dwarf) ewes at first lambing with initial body weight ranged from $20.33-24.4 \mathrm{~kg}$ were randomly distributed into three treatment group of 3 lactating ewes per replicate in a completely randomized design at the sheep unit, Teaching and Research Farms Directorate (TREFAD), of the Federal University of Agriculture Abeokuta, Ogun State, Nigeria. The ewes lambed between October and December. They were housed in 2 open sided pens with a wooden slated floor, raised a little above the ground. The animals were taken to the experimental pen 10 days after parturition. The animals were managed under an intensive system with zero grazing. They were fed with concentrate according to their diet group (Control, Low fiber High protein, High fiber Low protein), chopped grasses (panicum maximum) and water was given to the animals ad libitum (Table 1). Diets were offered twice daily at 6.00 and $16.00 \mathrm{hr}$. Residuals

\begin{tabular}{|l|c|c|c|}
\hline Ingredients & Control & Low fibre-High protein & High fibre-Low protein \\
\hline Maize & 10 & 10 & 8 \\
\hline Groundnut cake & 13 & 0 & 0 \\
\hline Palm kernel cake & 18 & 30 & 45 \\
\hline Rice husk & 37 & 38 & 45 \\
\hline Wheat/offal & 20 & 20 & 1 \\
\hline Salt & 1 & 1 & 1 \\
\hline Bone meal & 1 & 1 & 100 \\
\hline Total & 100 & 100 & 1753.4 \\
\hline Calculated analysis & & & 11.25 \\
\hline Metabolisable Energy & 1866.1 & 7912.1 & 4.686 \\
\hline (MKcal) & 16.455 & 16.856 & 22.22 \\
\hline Crude Protein\% & 5.199 & 4.595 & 0.648 \\
\hline Fat\% & 21.69 & 9.38 & 0.2734 \\
\hline Crude Fibre\% & 0.6608 & 0.4003 & 0.5178 \\
\hline Calcium\% & 0.2925 & 0.2497 & 0.2914 \\
\hline Av Phosphorus \% & 0.77240 & 0.4205 & \\
\hline Lysine \% & 0.3342 & 0.3024 & \\
\hline Methionine \% & & & \\
\hline
\end{tabular}

Table 1: Percentage composition of experimental diet.

${ }^{*}$ Corresponding author: Adewumi OO, Department of Animal Production and Health, Federal University of Agriculture, Abeokuta, Ogun State, Nigeria, E-mail: adewumioo@funaab.edu.ng

Received July 26, 2013; Accepted September 27, 2013; Published October 01, 2013

Citation: Adewumi OO, Ahmed AA (2013) The Effect of Fiber -Protein Levels on Milk Parameters, Linear Body Measurements and Udder Dimensions of West African Dwarf Sheep at First Lambing. J Veterinar Sci Technol S11: 007. doi:10.4172/2157-7579.S11-007

Copyright: (C) 2013 Adewumi OO, et al. This is an open-access article distributed under the terms of the Creative Commons Attribution License, which permits unrestricted use, distribution, and reproduction in any medium, provided the original author and source are credited. 
were weighed daily and subtracted from the offered amounts to obtain the actual feed consumed. Animals were weighed before feeding. Data pertaining to milk production and composition were compiled during one lactation period of 12 weeks. All lambs had access to the experimental diet of their dams.

The dams were taken into the experimental pen ten days after parturition to allow the lamb access to colostrums. The dams were hand milked once at $7 \mathrm{am}$ after isolation of lamb for $12 \mathrm{hrs}(7 \mathrm{am}-7 \mathrm{pm})$. The milk total solids, fat and protein and fat-protein ratio of the milk were analyzed in the laboratory.

Data on weight of dams and lambs at birth, feed-in-take, teat length, width circumference, height at withers, body length, heart girt, neck length, udder circumference, udder width, distant of teat from ground were collected on weekly bases. Milk samples were analyzed for protein, fat, total solids and ash using standard methods [4]. Milk Protein was analyzed by using titration method [4]. Milk fat was determined by separation method. Milk Total solid was determined by evaporation method.

\section{Statistical analysis}

Data generated was analyzed using One-Way analysis of variance as contained in SAS package [5]. Means was separated using Tukey's Studentized Range test.

\section{Result and Discussion}

Effect of dietary fiber protein levels on weight of dam, feed intake, milk parameters of WAD ewes at first lambing

The influence of diet on feed intake was significant $(\mathrm{p}<0.05)$ (Table 2). Mean milk offtake was significantly $(\mathrm{p}<0.01)$ lower (by about 15 and $37 \mathrm{ml}$ ) in ewes on HFLP and CTRL as compared to lactating ewes on LFHP diet. The overall average feed intake and milk offtake were
$1.09 \mathrm{~kg}$ and $197.46 \mathrm{ml}$ respectively. The effect of diet on to the fat and fat/protein ratio content of the milk was found to be highly significant $(\mathrm{p}<0.001)$ (Table 2). Average composition of milk parameters of WAD sheep for total solid, fat, protein and fat/protein ratio content were $14.52 \%, 6.18 \%, 6.73 \%$ and $0.99 \%$ respectively. No significant $(\mathrm{p}<0.05)$ difference was obtained among diets on total solids and proteins, however, lactating ewes on CTRL diet had higher values of total solids as compared to ewes on LFHP and HFLP diet while lactating ewes on LFHP had higher values of proteins as compared to ewes on CTRL and HFLP (Table 2). The fat/protein ratio for lactating ewes on CTRL and LFHP diet were significantly $(\mathrm{p}<0.001)$ higher as compared to ewes on HFLP diet.

Weight of dam, body measurements and udder dimensions were significantly $(\mathrm{p}<0.05)$ superior in animals on LFHP diet while wither height which was significantly higher in ewes on HFLP diet. Teat length was significantly $(\mathrm{p}<0.001)$ superior in ewes on CTRL diet.

The average linear body measurement and weight of WAD ewes at first lambing were $60.31 \mathrm{~cm}, 60.47 \mathrm{~cm}, 18.52 \mathrm{~cm}, 29.78 \mathrm{~cm}, 71.35$ $\mathrm{cm}$ for wither height, body length, neck length, neck circumference and heart girth respectively while the average udder dimensions were $27.93 \mathrm{~cm}, 15.07 \mathrm{~cm}, 2.69 \mathrm{~cm}, 4.41 \mathrm{~cm}, 10.64 \mathrm{~cm}$ and $34.72 \mathrm{~cm}$ for udder circumference, udder width, teat length, teat circumference and distance between teat (Table 3).

\section{Effect of dietary fiber -protein levels on lamb's weight and linear body measurement}

Table 4 shows the effect of dietary treatments on weight and linear body measurements of lambs. There was a significant $(\mathrm{p}<0.001)$ dietary effect on lamb's weight, wither height, heart girth and neck length. Lamb body length and circumference were not significantly affected. Weight and all body parameters were superior in ewes on LFHP. The

\begin{tabular}{|c|c|c|c|c|c|}
\hline Parameters & Control $\mathrm{N}=36$ & Low fibre-High protein $(n=36)$ & High fibre-Low protein $(n=36)$ & Overall mean $(n=108)$ & pvalue \\
\hline Feed intake $(\mathrm{kg})$ & $1.02 \pm 0.02^{\mathrm{b}}$ & $1.04 \pm 0.02^{b}$ & $1.09 \pm 0.02^{\mathrm{a}}$ & $1.05 \pm 0.01$ & $P<0.05$ \\
\hline Milk off-take (ml) & $177.36 \pm 7.09^{b}$ & $214.83 \pm 5.54^{\mathrm{a}}$ & $200.18 \pm 8.66^{a}$ & $197.57 \pm 45.38$ & $P<0.01$ \\
\hline Total solids (\%) & $14.76 \pm 0.37$ & $14.30 \pm 0.36$ & $14.52 \pm 0.44$ & $14.52 \pm 0.22$ & ns \\
\hline Fat $(\%)$ & $7.18 \pm 0.68^{\mathrm{a}}$ & $7.81 \pm 0.55^{\mathrm{a}}$ & $3.51 \pm 0.17^{b}$ & $6.18 \pm 0.35$ & $P<0.001$ \\
\hline Protein (\%) & $6.25 \pm 0.34$ & $7.23 \pm 0.33$ & $6.71 \pm 0.22$ & $6.73 \pm 0.18$ & ns \\
\hline Fat/protein (\%) & $1.27 \pm 0.17^{\mathrm{a}}$ & $1.15 \pm 0.09^{a}$ & $0.52 \pm 0.02^{b}$ & $0.99 \pm 0.07$ & $P<0.001$ \\
\hline
\end{tabular}

Table 2: Effect of dietary fibre-protein levels on weight, feed intake and milk parameters of WAD ewes at first lambing.

\begin{tabular}{|c|c|c|c|c|c|}
\hline Parameters & $\begin{array}{l}\text { Control } \\
\mathrm{N}=36\end{array}$ & $\begin{array}{l}\text { Low fibre-High protein } \\
\qquad(n=36)\end{array}$ & $\begin{array}{l}\text { High fibre-Low protein } \\
\qquad(n=36)\end{array}$ & Overall mean $(n=108)$ & pvalue \\
\hline Weight of dam (cm) & $23.74 \pm 0.77^{\mathrm{b}}$ & $26.93 \pm 0.32^{a}$ & $24.08 \pm 0.61^{b}$ & $24.84 \pm 0.37$ & $P<0.001$ \\
\hline \multicolumn{6}{|l|}{ Linear Body Measurements } \\
\hline Wither height $(\mathrm{cm})$ & $60.86 \pm 0.52^{\mathrm{a}}$ & $58.44 \pm 0.90^{b}$ & $61.64 \pm 0.77^{\mathrm{a}}$ & $60.31 \pm 0.45$ & $\mathrm{P}<0.01$ \\
\hline Body length (cm) & $57.64 \pm 0.79^{b}$ & $62.89 \pm 0.54^{\mathrm{a}}$ & $61.06 \pm 0.94^{\mathrm{a}}$ & $60.47 \pm 0.49$ & $P<0.001$ \\
\hline Neck length $(\mathrm{cm})$ & $17.39 \pm 0.43^{\mathrm{ab}}$ & $20.97 \pm 1.78^{a}$ & $17.22 \pm 0.53^{b}$ & $18.52 \pm 0.65$ & $P<0.05$ \\
\hline Neck circumference $(\mathrm{cm})$ & $28.60 \pm 0.13^{\mathrm{b}}$ & $31.22 \pm 0.41^{\mathrm{a}}$ & $29.39 \pm 0.36^{b}$ & $29.78 \pm 2.58$ & $P<0.001$ \\
\hline Heart girth $(\mathrm{cm})$ & $71.17 \pm 0.22$ & $71.50 \pm 0.75$ & $71.39 \pm 0.73$ & $71.38 \pm 0.35$ & ns \\
\hline \multicolumn{6}{|l|}{ Udder dimensions } \\
\hline Udder circmference $(\mathrm{cm})$ & $27.78 \pm 0.29^{b}$ & $31.36 \pm 0.60^{a}$ & $24.72 \pm 0.38^{c}$ & $27.93 \pm 0.37$ & $P<0.001$ \\
\hline Udder width (cm) & $14.80 \pm 0.22$ & $15.28 \pm 0.38$ & $15.07 \pm 0.70$ & $15.07 \pm 0.27$ & ns \\
\hline Teat length $(\mathrm{cm})$ & $2.92 \pm 0.05^{\mathrm{a}}$ & $2.61 \pm 0.08^{b}$ & $2.56 \pm 0.08^{b}$ & $2.69 \pm 0.04$ & $\mathrm{P}<0.01$ \\
\hline Teat circumference $(\mathrm{cm})$ & $3.82 \pm 0.10^{b}$ & $4.67 \pm 0.20^{a}$ & $3.82 \pm 0.20^{b}$ & $4.41 \pm 0.11$ & $P<0.001$ \\
\hline Distance between teats $(\mathrm{cm})$ & $10.58 \pm 0.13^{\mathrm{b}}$ & $11.11 \pm 0.15^{\mathrm{a}}$ & $10.25 \pm 0.18^{b}$ & $10.64 \pm 0.01$ & $P<0.001$ \\
\hline Distance of teat from ground $(\mathrm{cm})$ & $31.97 \pm 0.34^{b}$ & $35.89 \pm 0.44^{a}$ & $36.31 \pm 0.68^{a}$ & $34.72 \pm 0.35$ & $P<0.001$ \\
\hline
\end{tabular}

Table 3: Effect of dietary fibre-protein levels on linear body measurements and udder dimensions of WAD ewes at first lambing. 


\begin{tabular}{|l|c|c|c|c|}
\hline Parameters & Control & Low fibre-High protein & High fibre-Low protein & Overall mean $(\mathrm{n}=108)$ \\
\hline Weight of lamb $(\mathrm{kg})$ & $5.65 \pm 0.34^{\mathrm{ab}}$ & $6.25 \pm 0.44^{\mathrm{a}}$ & $4.71 \pm 0.23^{\mathrm{b}}$ & $5.50 \pm 0.21$ \\
\hline Lamb wither height $(\mathrm{cm})$ & $45.03 \pm 0.62^{\mathrm{b}}$ & $49.06 \pm 0.57^{\mathrm{a}}$ & $44.36 \pm 1.13^{\mathrm{b}}$ & $46.15 \pm 0.51$ \\
\hline Lamb body length $(\mathrm{cm})$ & $38.43 \pm 0.57$ & $38.83 \pm 0.73$ & $37.18 \pm 0.49$ & $38.15 \pm 0.35$ \\
\hline Lamb heart girth $(\mathrm{cm})$ & $49.90 \pm 1.57^{\mathrm{ab}}$ & $50.65 \pm 1.43^{\mathrm{a}}$ & $44.71 \pm 1.21^{\mathrm{b}}$ & $48.42 \pm 0.85$ \\
\hline Lamb neck length $(\mathrm{cm})$ & $12.92 \pm 0.50^{\mathrm{ab}}$ & $14.78 \pm 0.39^{\mathrm{a}}$ & $12.01 \pm 0.57^{\mathrm{b}}$ & $13.24 \pm 0.30$ \\
\hline Lamb neck circumference $(\mathrm{cm})$ & $21.69 \pm 0.48$ & $23.24 \pm 0.36$ & $21.67 \pm 0.54$ & $\mathrm{Ps}$ \\
\hline
\end{tabular}

Table 4: Effect of dietary fibre-protein levels on weight and linear body measurement of lambs.

mean lamb's weight, wither height, body length, heart girth, neck length and neck circumference were $5.50 \mathrm{~kg}, 46.15 \mathrm{~cm}, 38.15 \mathrm{~cm}, 48.42 \mathrm{~cm}$, $13.24 \mathrm{~cm}$ and $22.20 \mathrm{~cm}$ respectively.

\section{Discussion}

Ewes fed high fiber diets spent more time eating as compared to ewes on CTRL and HFLP diet. The increased feed intake of the birds on HFLP diet is expected because of the high fiber which tends to increase the total fiber content of the diets thereby diluting other nutrients. For the ewes to meet their energy requirements to maintain rapid growth and development, they consumed more feed. Abdel-Rahman and Mehaia [6] reported feed intake of $1.95 \mathrm{~kg} /$ day for lactating Nadja ewes in Saudi Arabia.

The milk offtake was generally low. The poor performance is not a new phenomenon as it has been reported elsewhere [7,8]. For instance, the East Friesland and Scottish Black ewes in the temperate produced about 2.4 litres/ day [9]. The main reason seems to be that most of the indigenous sheep in the tropics are for meat while the sheep in the temperate environment have been highly selected for milk production. Also, less favourable environment, inadequate nutrition due to variation in the quality of feedstuffs, as feed ingredients available in the natural environment of the exotic breeds could be of better quality. The low milk yield could also be due to genetic factors and previous handling due to the fact that the West African Dwarf had never been subjected to milking process except suckling. However, the West African Dwarf in the tropics in a previous study produced $122 \mathrm{ml}$ [10] under semiintensive and extensive management system respectively. Milk offtake was slightly lower than the result obtained in this study. The high milk offtake obtained in this study as compared to the report obtained in previous studies was mainly because the lactating ewes in this present study were raised under the intensive system of management.

The high milk offtake in ewes on LFHP diet could be as a result of the protein concentration in the LFHP diet. This result was found to be consistent with the report by Robinson et al. [11], which states that an increase in dietary protein concentration without a change in energy intake will increase the milk yield if ewe has not reached her potential yield. The average protein content is slightly lower than $5.8 \mathrm{~g} / \mathrm{l}$ obtained by Sakult and Boylan, [12] in temperate and 5.52\%, 6.07\%, and 5.43\% reported in tropical breeds of sheep $[3,13]$. Body weight, all the body traits and composition observed in this study were higher than values obtained by Kominakis et al. [2] except for protein content. Generally, the milk composition is comparable to that obtained in the temperate breeds. A low milk yield has been associated with high milk content in lactating ewes in the tropics [14].

The fat/protein ratio and does not indicate fiber surplus and deficiency. However, the fat/protein ratio ratio observed in animals in animals on HFLP diet indicated fiber deficiency and energy surplus. Malau-Aduli and Anlade [13] reported that protein and SNF (Solid-nonfat) percentages were significantly increased by reducing fiber content whereas fat and TS (Total Solids) percentages significantly increased by increasing crude fiber in the diet but in our report, increased crude fiber decreased fat content significantly. Banik et al. [15] suggested that a milk fat/protein ratio of 1.1-1.5 could be taken as optimal and the greater than 1.5 could indicate energy deficiency and fiber surplus in ration while the milk fat/protein ratio less than 1.1 indicates fiber deficiency and energy surplus. The mean fat-protein ratio obtained in this study was comparable to that reported by Alphonsus et al. [16] in Friesian $\mathrm{x}$ Bunaji cows.

The total solids value reported in this study was in consonance with 16.3\% obtained by Jenness [17] and $15.61 \%$ obtained by Andreas [18] but the milk fat content was higher than $5.3 \%$ reported by Jenness [17] and similar to $6.04 \%$ obtained by Andreas [18]. The low fiber and high fiber diet tend to produce significantly higher milk fat. This is consistent with the findings of Bocquier and Caja [19]. The result was due to high inclusion of dietary protein as suggested by Bocquier and Caja [19] which state that dietary protein has positive correlation with milk fat content.

The average weight and wither height of about $25 \mathrm{~kg}$ and $60 \mathrm{~cm}$ respectively were higher than that reported on West African Dwarf sheep in a previous study [20]. However another study working with Yankasa, Yankasa x WAD crosses and Frizarta dairy sheep, reported a higher weight and wither height $[2,8]$ than in the current study. Variations with other studies might be contributed by genetics, climatic conditions and management practices. The significantly higher wither height in ewes on HFLP diet implies that lactating ewes on this diet are generally taller, hence they cannot be used as meat animal. Generally, the mean body length, heart girth, udder circumference, udder width, teat length, teat circumference, distance between teat and distance of teat from ground were lower than that reported elsewhere [2,8,20-22].

\section{Effect of dietary fiber protein levels on lamb's weight and linear body measurements}

Lambs of dams on low fiber high protein had the highest value of weight and linear body measurements. The lambs on high-fiber lowprotein level of inclusion however recorded the least value of weight. These values were comparable with those values reported by Adewumi and Olorunisomo [3].

\section{Conclusion}

Based on the result obtained from this research, it can be concluded that the lactating ewes on LFHP diet were significantly superior in milk and body parameters.

\section{Recommendation}

It is then recommended from this experiment that high quality milk offtake can be harvested with high dietary protein level in the diet of lactating ewe at first parity.

\section{References}

1. Treacher TT (1971) Effects of nutrition in late pregnancy on subsequent milk production in Ewes. Anim Prod 12: 23-36. 
Citation: Adewumi OO, Ahmed AA (2013) The Effect of Fiber -Protein Levels on Milk Parameters, Linear Body Measurements and Udder Dimensions of West African Dwarf Sheep at First Lambing. J Veterinar Sci Technol S11: 007. doi:10.4172/2157-7579.S11-007

2. Kominakis AP, Papavasiliou D, Rogdakis E (2009) Relationship among udder characteristics, milk yield and non-yield traits in Frizarta dairy sheep. Smal Ruminant Research 84: 82-88.

3. Adewumi OO, Olorunisomo O (2009) Milk yield and milk composition of Yankasa, West African Dwarf sheep and their crossbred sheep in South West of Nigeria. Livestock Research for Rural Development 21

4. Pearson DJ (1998) The chemical Analysis of foods. Chemical Publication. Inc.

5. SAS (2002)Statistical Analysis systems for mixed models. SAS Institute Inc. Cary, NC, USA.

6. Abdel-Rahman KM, Mehaia MA (1996) Influence of feeding different crude fiber levels on milk yield and milk composition of Najdi ewes. Small Ruminant Research 19: 137-141.

7. Agbede JO, Ologun AG, Alokan JA (1997) Udder size and milk production potentials of goats and sheep in the Southwest of Nigeria. Journal for Animal Production 24: 175-119.

8. Adewumi OO, Alokan JA, Ologun AG (2003) The relationship between some body measurements and milk yield of lactating ewes. Journal of Agriculture, Forestry and Fisheries 4: 44-48.

9. Rhind SM, Bass J, Doney JM (1992) Pattern of milk production of Eas Friesland and Scottish Blackface ewes and associated blood metabolite and hormone profiles. British Society of Animal Production 54: 265-273.

10. Adewumi OO, Chineke CA, Alokan JA, James IJ, Akinola OA (2011) The effects of genotype and week of lactation on milk yield, udder dimensions and linear body measurements of non-dairy ewes. Nigerian Journal of Animal Production 38: 9-17. Published by the Nigerian Society for Animal Production.

11. Robinson JJ, Mc Hattie I, Calderon-Cortes JF, Thompson JL (1979) Furthe studies on the response of lactating ewes to dietary protein. Anim Prod 29 : 257-269.

12. Sakult H, Boylan WJ (1992) Lactation curves for several US sheep breeds. Journal of Animal Production 54: 229-233.
13. Malau-Aduli AEO, Anlade YR (2002) Variations and correlations in the composition of bovine, ovine and caprine milk. Proceeding of the $26^{\text {th }}$ Anima Conference of the Nigerian Society for Animal Production. Ahmadu Bello University, Zaria.

14. Adewumi OO, Alokan JA, Ologun AG (2005) Milk yield, chemical constituents and stage of lactation in sheep. Proceeding of the 10th Annual Conference of Animal Science Association of Nigeria. University of Ado-Ekiti, Ekiti State, Nigeria.

15. Banik D, Verbic J, Podgorsek P, Jeretina J, Perpar T, et al. (2004) Handbook for the management of nutrition of dairy cows the assistance of the mammary inspection results. Agricultural Institute of Slovenia, Ljubljana.

16. Alphonus C, Akpa GN, Barje PP, Nwagu BI, Orunmuyi M (2012) The variation of milk fat-protein within the first 120 day lactation of Friesian $x$ Bunaji cows. Proceeding of the $37^{\text {th }}$ Animal Conference of the Nigerian Society for Animal Production. University of Agriculture Markudi Markurdi Nigeria. 80-83

17. Jenness R (1980) Composition and characterization of sheep milk.Reviewed 1968 - 1979. Journal of Dairy Science 63: 1605-1630.

18. Andreas P (1979) Protein requirement of lactating ewe. Journal of Animal Science 44

19. Bocquier F, Caja G (1993) Effect of nutrition on the composition of sheep milk. In: Ledin I, Morand-Fehr P (Eds) Sheep and goat nutrition: Intake, digestion, quality of products and rangelands.

20. Adewumi OO, Badepade EG (2006) Phenotypic variation among milk yield and physical body characteristics of Yankasa and Yankasa X WAD ewes. African Journal of Science 1: 38-41.

21. Salako AE, Ngere LO (2002) Application of multi-factorial discriminant analysis in the morphomerric structure differentiation of West African Dwarf (WAD) and Yankasa sheep in south West Nigerian. Nig J Anim Prod 29: 163-167.

22. Afolayan RA, Adeyinka IA, Lakpini CAM (2006) Prediction of live-weight from objective live-dimensional traits in Yankasa sheep. Proceedings of the 31st Annual Conference of the Nigerian Society for Animal Production (NSAP). Bayero University Kano. 